\title{
The production of biopharmaceuticals in Brazil: current issues
}

\author{
Marcela Valente Pimenta ${ }^{1}$, Gisele Monteiro ${ }^{\circledR 1^{*}}$ \\ ${ }^{1}$ Department of Biochemical-Pharmaceutical Technology, Faculty of Pharmaceutical Science, \\ University of Sao Paulo, SP, Brazil
}

\begin{abstract}
Biopharmaceuticals are gaining a growing share of the pharmaceuticals market. In recent years, the Brazilian Health Surveillance Agency (ANVISA) has approved the registration of biological drugs with domestic production. Although Brazil is in the early stages of biopharmaceutical production, governmental incentives and the investment in private companies in the technological domain in this country have created expectations of an increase in the capacity of biopharmaceutical production. Private initiatives, once rare, have now started to blossom in this field, such as collagenase from Cristalia and filgrastim from Eurofarm. The expiry of the patents for certain biopharmaceuticals (e.g. infliximab, filgrastim and rituximab) has generated the possibility of savings to the Brazilian National Health System (SUS) in terms of biosimilars and incentives for national production. National production could also avoid dependence on external imports and a lack of essential supplies. In the next few years, Brazil is expected to bring nationally produced biopharmaceuticals to the market. Although there is some way to go before Brazil will be able to sustain the national demand for biopharmaceuticals and supply international markets with new products, the country is starting to take its first steps towards these objectives.
\end{abstract}

Keywords: Biopharmaceutical. Biosimilar. Biological drugs. Brazilian biopharmaceutical market

\section{INTRODUCTION}

According to the Food and Drug Administration Agency (FDA), biopharmaceuticals are complex molecules produced by an organism or a cell, and are used in medicine for healing, remedial, corrective or restorative replacements or treatments (FDA, 2017). Biopharmaceuticals can be broadly divided into three main classes: therapeutic proteins (e.g. asparaginase, insulin and imiglucerase), monoclonal antibodies ( $\mathrm{mAb}$, e.g. infliximab and adalimumab) and vaccines. In 1978, scientists from Genentech created the recombinant hormone insulin, produced by Escherichia coli. This was the first biopharmaceutical using recombinant DNA technology. Before this, insulin had been obtained from porcine and bovine pancreas, and faced obstacles to large-scale production, and adventitious and dangerous contaminants such as viruses (Tibaldi, 2012).

Nowadays, the pharmaceutical market offers several types of insulin, including short-, intermediate- and longacting forms and biphasic insulins that can reduce the

\footnotetext{
*Correspondence: G. Monteiro. Departamento de Tecnologia BioquímicoFarmacêutica, Faculdade de Ciências Farmacêuticas, Universidade de São Paulo, São Paulo, Brazil. Tel.: +55 11 3091-3734. E-mail: smgisele@usp.br
}

number of injections required. The natural biosynthesis of insulin starts with a peptide in which the aminoterminal portion contains a signal-sequence, followed by a segment called the $\mathrm{B}$ chain, an intermediated linker called the $\mathrm{C}$ chain, and an A chain in the carboxy-terminal portion. During processing, the signal-sequence and the $\mathrm{C}$ chain are cleaved, and two disulphide bonds contain chains A and B. In human recombinant insulin, only the $\mathrm{A}$ and $\mathrm{B}$ chains are synthesised by $E$. coli. Both peptides are linked by disulphide bounds through a redox process (Tibaldi, 2012; Goeddel et al., 1979). DNA recombinant technology offers the possibility of treating diseases caused by a lack of peptide hormones or even enzyme deficiency.

In the 1970s, the native E. coli enzyme asparaginase began to be used as a biopharmaceutical in leukaemia treatment. Asparaginase catalyses asparagine (Asn) hydrolysis in glutamine (Gln) and ammonium. Leukemic cells are dependent on an external source of Asn, which is depleted in the serum by the use of asparaginase, causing proper protein synthesis to fail and apoptosis to be initiated (Avramis, 2012). Asparaginase and insulin are peptides with no requirement for sophisticated post-translational modification (PTM), such as in glycosylation. 
With an increase in PTM complexity, the organism for heterologous expression needs to be more evolved. Yeasts such as Saccharomyces cerevisiae and Pichia pastoris can be used to produce glycoproteins, instead of bacteria such as $E$. coli. However, the glycosylation pattern is different to that found in humans, causing an unwanted immune response in the patient (Josala et al., 2016; Scott, Allison, Wolchok, 2012).

The expression platform most often used to produce recombinant glycoproteins is Chinese hamster ovary cells $(\mathrm{CHO})$, since these have a glycosylation pattern close to that in humans, grow in suspension, have a lower chance of contamination with human viruses and have been very well accepted by regulatory agencies for the approval of drugs (Durocher, Butler, 2009).

Glycosylation requirements affect the production of one of the most important class of biopharmaceuticals, the mAb. The possibility of using mAb to target cell receptors vastly increased the number of available therapies. Infliximab and adalimumab are examples of $\mathrm{mAbs}$ targeting the tumour necrosis factor alpha (TNF- $\alpha$ ) pathway, and are used in many conditions to control inflammation, such as in rheumatoid arthritis, Crohn's disease and psoriasis (Kalden, Schulze-Koops, 2017).

In terms of cancer therapy, mAbs are used for several aims, such as cell growth factors (e.g. trastuzumab - Her2, bevacizumab - VEGF, cetuximab and panitumab - EGFR), tumour antigens (e.g. rituximab, ofatumumab, alentuzumab and ofatumumab), immune checkpoints, restoring the ability of T cells to fight cancer (e.g. ipilimumab), or even for the delivery of toxic payloads or radioisotopes (e.g. gemtuzumab, brentuximab vedotin, 90Y-ibritumomab and 131I-tositumomab) (Kesik-Brodacka, 2018; Scott, Allison, Wolchok, 2012; Tsai, Hsu 2017).

The market share of biological drugs is increasing each year. Projections indicate a value of USS 287 bn by 2020 , led mainly by mAb and insulins (Walsh, 2014; Transparency Market Research, 2018).

Due to the high cost of this class of medicine and the new technologies used in the fabrication process, Brazil is in the early stages of domestic production of biopharmaceuticals. The aim of this review is to position Brazil in the context of biopharmaceutical production.

\section{Biopharmaceutical production - overview of the problem}

A biological drug is significantly more complex than a synthetic drug. For example, the synthetic drug paracetamol has a molecular weight of $151.15 \mathrm{~g} / \mathrm{mol}$, and the chemical formula $\mathrm{C}_{8} \mathrm{H}_{9} \mathrm{NO}_{2}$, while infliximab, an $\mathrm{mAb}$, has a molecular weight of $144,190.3 \mathrm{~g} / \mathrm{mol}$ and the chemical formula $\mathrm{C}_{6426} \mathrm{H}_{9912} \mathrm{~N}_{1694} \mathrm{O}_{1987} \mathrm{~S}_{46}$, i.e. three orders of magnitude greater (Figure 1). It is economically infeasible to synthesise a complex structure such as a biological drug by chemical means.

The expiry of the first biopharmaceutical patents opened the way for the pharmaceutical industry to produce and commercialise the same biological drugs under different trademarks (Tsuruta, Santos, Moro, 2015). However, in the specific case of biopharmaceuticals, the process of ensuring regulatory equivalence for a new trademark is much more complicated than that necessary for synthetic drugs, due to the greater possibility of differences in the processing of biological molecules having a direct impact on their quality and therapeutic effects.

Biosimilars have the same relationship to biopharmaceuticals as that of generic drugs to synthetic ones. Infliximab was the first biosimilar $\mathrm{mAb}$ approved by the European Medicines Agency (EMA). Remsima ${ }^{\circledR}$, produced by Celltrion Healthcare $($, was recently approved

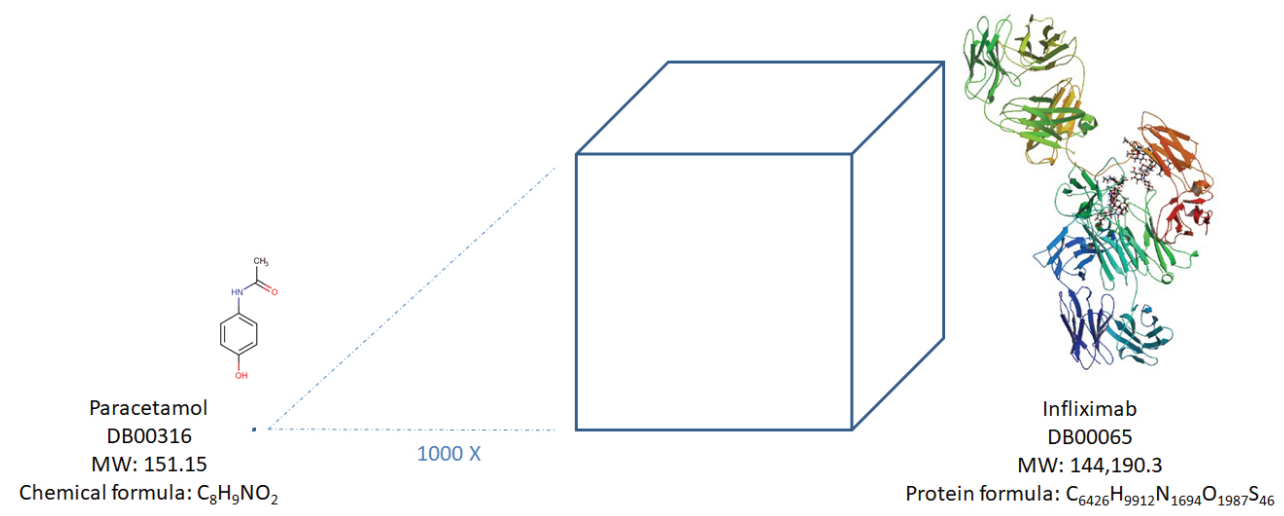

FIGURE 1 - Comparison of a synthetic drug with a biological drug. A: the structure of Paracetamol, a small molecule usually used as an analgesic and antipyretic. B: The structure of Infliximab, a monoclonal antibody (mAb) used in rheumatoid arthritis treatment among other diseases. Adapted from: https://www.drugbank.ca. 
in 2013; the reference drug for this was Remicade $\mathbb{R}$, produced by Janssen Global Services $\subset$ which had been authorised by EMA since 1999. In process of regulation of Remsima ${ }^{\circledR}$, different methodologies were utilised to access the molecule feature and ensure similar efficacy for the drug. Its protein structure, purity and glycosylation were studied using sophisticated techniques such as circular dichroism spectroscopy, differential scanning calorimetry, enzyme-linked immunosorbent assay (ELISA), electrospray ionisation mass spectrometry (LC-ESI-MS), size-exclusion chromatography and cellbased assays, among others (Tsuruta, Santos, Moro, 2015). These aspects mean that the regulatory process for biosimilars is more complex than for generic drugs (Kesik-Brodacka, 2018).

In addition to the factors described above, the cost of treatment with biological drugs is usually higher than for synthetic drugs. For example, annual treatment of rheumatoid arthritis in the United States with conventional drugs costs US\$755, compared to US $\$ 15,933$ with biological drugs (Transparency Market Research, 2018).

\section{The Brazilian Context}

According to a UNESCO Science Report (UNESCO, 2015), Brazil is the only Latin American country with levels of investment in research and development (R\&D) and scientific production equivalent to that of emerging economies. With a $2.9 \%$ share of global publications, Brazil is a major player in the fields of science, technology and innovation in Latin America. However, the country's pharmaceutical companies have low levels of R\&D investment, and encounter difficulties in bringing innovations onto the market (UNESCO, 2015).

The Brazilian National Health System (SUS, Sistema Único de Saúde) divides the acquisition of medicines into three groups; basic, strategic and specialised. For specialised medicines (Groups 1A and 1B), the financing is exclusive to the Brazilian Government, and SUS expenditure was $\mathrm{R} \$ 7.1$ billion in 2016. Alongside many synthetic drugs, this subdivision contains most of the biopharmaceuticals; the exception is vaccines, which fall into the strategic group. More than $50 \%$ of the above SUS expenditure was on biopharmaceuticals, despite the fact that they represent only $4 \%$ of the total quantity of medicines acquired (Portal da Saúde, 2018). This discrepancy highlights the need for national production of biological drugs. Moreover, national production would diminish the dependency on the external market. There is frequently a lack of national supply of medicines due to commercial issues. In August 2012, the Oso
Biopharmaceutical company informed several countries of their suspension of L-asparaginase production, leading to a lack of this essential drug for leukaemia treatment in Brazil (Brasil, 2017a).

In 2015, ANVISA approved the first biosimilar for national commercialisation, Remsima ${ }^{\circledR}$ (infliximab). This had first been approved by EMA in 2013 (Tsuruta, Santos, Moro, 2015), and the reference drug for this was Remicade $^{\circledR}$ (C Janssen-Cilag). This approval created the possibility of a reduction in the cost of the medicine, since biosimilars have a lower price than the reference product. Remicade $^{\circledR}$ is made in Switzerland, Ireland, Belgium and United States of America (USA), whereas the biosimilar Remsima ${ }^{\circledR}$ is produced in South Korea by Celltrion Inc.

\section{Biopharmaceutical production in Brazil}

Biobrás, a pioneer company in the development of biopharmaceuticals in Brazil, started the insulin purification of bovine and porcine pancreas origin and delivered the feedstock to Eli Lilly, which purified and formulated the insulin in the final product. In 1983, Briobrás became a pharmaceutical company, and no longer supplied raw material to Eli Lilly. Despite having achieved large-scale production of recombinant human insulin in 1999, Biobrás did not continue in business due to the low prices offered by the international market. In 2001, Biobrás was acquired for US $\$ 31$ million by Novo Nordisk (Ferreira, 2008). In October 2017, Biomm (a successor of Biobrás) announced a partnership with MannKind Corporation (California, USA) to register with ANVISA and commercialise $A$ frezza ${ }^{\circledR}$, an inhaled form of insulin (taken from Biomm website, Table II).

Brazil is self-sufficient in the production of several types of vaccines; for example, vaccines against hepatitis $\mathrm{B}$, diphtheria, tetanus, and pertussis are produced by the Butantan Institute, an intradermal BCG vaccine by Fundação Ataulpho Paiva, and yellow fever vaccine by Bio-manguinhos/Fiocruz. These institutions have also formed partnerships with for-profit producers such as GSK (technology transfer agreements with Bio-manguinhos/Fiocruz to produce vaccines for Hib (Haemophilus influenzae b), OPV (oral polio vaccine), Rotavirus (monovalent oral human rotavirus vaccine), Pneumococcal 10-valent conjugate vaccine and MMR (measles, mumps, and rubella)); Novartis (technology transfer agreement with Fundação Ezequiel Dias, MG, to produce meningitis $\mathrm{C}$ conjugate vaccine) and Sanofi Pasteur (technology transfer agreements with Instituto Butantan to produce seasonal influenza and H1N1 influenza vaccines). All of these biopharmaceuticals are 
produced for a free vaccination program undertaken by the Health Ministry to immunise Brazilian citizens (for a complete review of Brazilian vaccines, see Ho et al., 2011).

\section{Partnerships for productive development}

The Brazilian pharmaceutical industry benefits from government incentives to improve the national production of medicines with high cost. Partnerships for productive development (PDP, Parcerias para o Desenvolvimento Produtivo) between public and private institutions have been formed for the production of strategic medicines for the Unic Brazilian health system. In March 2017, the Health Ministry (MS, Ministério da Saúde) published a list of strategic interest products, which contained 56 pharmaceutical components for Brazilian development, of which 23 were biopharmaceuticals (Table I). The Health Ministry planned to provide facilities for the national manufacturing of these components. It received 83 proposals for production, 15 of which involved 11 biopharmaceuticals (Brasil, 2017b; Brasil, 2017c). The MS approved eight proposals for biopharmaceuticals, to produce adalimumab, agalsidase beta, certolizumab, golimumab, imiglucerase, insulin glargine, palivizumab and tocilizumab (DOU, 2018; Table I). Future PDP projects can be followed at http://portalms.saude.gov.br/ ciencia-e-tecnologia-e-complexo-industrial/complexoindustrial/parceria-para-o-desenvolvimento-produtivopdp.

In order to reach a level of international competitiveness, some Brazilian pharmaceutical industries formed joint ventures. Bionovis is a joint venture involving Aché, EMS, Hypermarcas and União Quimica; these companies have formed a partnership with Janssen and Merck, who have agreed to supply them with production technology including a master cell bank for eight biopharmaceuticals. In addition, other products have been developed internally. In the pipeline for production by Bionovis are trastuzumab, bevacizumab, etanercept, rituximab, adalimumab, and two other drugs that have been developed (Bionovis website, Table II).

Orygen Biotecnologia is a joint venture formed by Biolab, Cristália and Eurofarma in order to research, develop, produce, commercialise and import biopharmaceuticals. However, no product has yet been registered with ANVISA, and no publications about which drugs are being developed have been produced (CADE, 2013).

The pharmaceutical company Libbs has built its own plant, called Biotec, to produce mAb biopharmaceuticals, and the production of rituximab, etanercept, bevacizumab and adalimumab is currently planned. Although production has already started in Brazil, these products have not yet been launched on the market. Libbs has also registered trastuzumab, which will be produced by PDP (Libbs website, Table II).

A public company called TECPAR, (TECPAR website, Table II) has established the production of immunobiologicals mainly for veterinary use, for example the rabies vaccine. It has set up projects to produce trastuzumab, infliximab, rituximab, adalimumab, bevacizumab and etanercept for SUS, and also intends to produce agalsidase beta, imiglucerase and haemoderivatives.

EuroFarma produces the first biosimilar to be entirely manufactured in Brazil, called Fiprima ${ }^{\circledR}$ (filgrastim), and began the commercialisation of this in 2016. The reference product is Granilokine ${ }^{\circledR}$ Roche. Filgrastim is a human granulocyte colony stimulating factor (G-CSF), a non-glycosylated protein from a prokaryotic source used to treat neutropaenia, mostly in an oncological context (DOU, 2015).

Commercial permission for drugs in Brazil is granted by ANVISA, through a drug registration process. These registers are public and can be accessed through the website http://portal.anvisa.gov.br/consulta-produtosregistrados, which contains fields allowing the registration of national and international manufacturers. Registration of the manufacturer only constitutes authorisation for manufacture, and does not necessarily mean that drugs are produced in this particular locality. From the records of filgastrin found to date ( $7^{\text {th }}$ December 2017), Aché and Blau have also registered filgrastin with a national manufacturer; however, in ANVISA, this registration appears for another international manufacturer. From publicly available knowledge, it is therefore impossible to say whether this drug is produced in Brazil, abroad or both.

The same situation holds for the interferon Alfa$2 \mathrm{~b}$ recombinant used in the treatment of leukaemia and melanoma, among other diseases. It is commercialised by Biosintética and Fundação Oswaldo Cruz, and both ANVISA registrations contain an international and a national manufacturer. Erythropoietin has six Anvisa registrations, which four have domestic and international manufacturers: Biosintétic (from the Aché group), Blau (with two registers; Alfaepoetina ${ }^{\circledR}$ and Eritromax ${ }^{\circledR}$ ), and Fundação Oswaldo Cruz.

Cristália owns plants that produce biopharmaceuticals from prokaryote or eukaryote expression platforms. Trastuzumab, etanercept and somatotropin are undergoing the clinical trials required for the registration of biological 
TABLE I - Biopharmaceutical in the List of Strategic Interest Products and Proposals received

\begin{tabular}{|c|c|c|c|c|}
\hline Biopharmaceutical & Class & Function & $\begin{array}{c}\text { PDP Proposals } \\
\text { public institutions }+ \text { private } \\
\text { institutions } \\
\end{array}$ & \\
\hline Abatacept & $\mathrm{mAb}$ & anti-inflammatory & - & \\
\hline Alpha-galactosidase & enzyme & Fabry's disease treatment & - & \\
\hline Amphotericin B & antifungal & $\begin{array}{c}\text { fungal infection } \\
\text { treatment }\end{array}$ & - & \\
\hline $\begin{array}{l}\text { Amphotericin B } \\
\text { liposomal }\end{array}$ & antifungal & $\begin{array}{l}\text { fungal infection } \\
\text { treatment }\end{array}$ & - & \\
\hline Dactinomycin & antineoplastic & cancer treatment & - & \\
\hline Eculizumab & $\mathrm{mAb}$ & $\begin{array}{c}\text { paroxysmal nocturnal } \\
\text { hemoglobinúria } \\
\text { treatment }\end{array}$ & - & \\
\hline Galsufase & enzyme & $\begin{array}{c}\text { Mucopolysaccharidosis } \\
\text { VI treatment }\end{array}$ & - & \\
\hline Ipilimumab & $\mathrm{mAb}$ & cancer treatment & - & \\
\hline Asparaginase & enzyme & $\begin{array}{l}\text { acute lymphoblastic } \\
\text { leucemia treatment }\end{array}$ & - & \\
\hline Peg-asparaginase & enzyme & $\begin{array}{c}\text { acute lymphoblastic } \\
\text { leucemia treatment }\end{array}$ & - & \\
\hline Natalizumab & $\mathrm{mAb}$ & $\begin{array}{c}\text { multiple sclerosis } \\
\text { treatment }\end{array}$ & - & \\
\hline Botulinum Toxin & acetylcholine blocker & Dystonia treatment & - & \\
\hline Adalimumab $^{1}$ & $\mathrm{mAb}$ & anti-inflammatory & $\begin{array}{c}\text { Butantan institute }+ \text { Libbs } \\
\text { TECPAR } \\
\end{array}$ & Approved \\
\hline Adalimumab $^{2}$ & $\mathrm{mAb}$ & anti-inflammatory & Biomanguinhos + Bionovis & Disapproved \\
\hline Adalimumab $^{3}$ & $\mathrm{mAb}$ & anti-inflammatory & +Orygen Biotecnologia & Disapproved \\
\hline Agalsidase beta & enzyme & Fabry's disease & TECPAR+Genzyme & Approved \\
\hline Certolizumab pegol & $\mathrm{mAb}$ & anti-inflammatory & Biomanguinhos + Bionovis & Approved \\
\hline Golimumab & $\mathrm{mAb}$ & anti-inflammatory & Biomanguinhos + Bionovis & Approved \\
\hline Imiglucerase & enzyme & Gaucher's disease & TECPAR+Genzyme & Approved \\
\hline Insulin Aspart & insulin analogue & $\begin{array}{c}\text { Type } 1 \text { or } 2 \text { diabetes } \\
\text { mellitus }\end{array}$ & Bahia Farma+Indar & Disapproved \\
\hline Insulin Glargine $^{1}$ & insulin analogue & $\begin{array}{c}\text { Type } 1 \text { or } 2 \text { diabetes } \\
\text { mellitus }\end{array}$ & $\begin{array}{c}\text { FUNED+Biomm } \\
\text { Butantan + Gan \& Lee } \\
\text { Pharmaceuticals } \\
\end{array}$ & Approved \\
\hline Insulin Glargine $^{2}$ & insulin analogue & $\begin{array}{c}\text { Type } 1 \text { or } 2 \text { diabetes } \\
\text { mellitus }\end{array}$ & Bahiafarma+INDAR & Disapproved \\
\hline Insulin Glargine $^{3}$ & insulin analogue & $\begin{array}{c}\text { Type } 1 \text { or } 2 \text { diabetes } \\
\text { mellitus }\end{array}$ & Butantan+Sanofi Aventis & Disapproved \\
\hline Nivolumab & $\mathrm{mAb}$ & cancer treatment & Biomanguinhos + Bionovis & Disapproved \\
\hline Palivizumab & $\mathrm{mAb}$ & $\begin{array}{c}\text { respiratory syncytial } \\
\text { virus. }\end{array}$ & Butantan + Libbs & Approved \\
\hline Pembrolizumab & $\mathrm{mAb}$ & cancer treatment & Biomanguinhos + Bionovis & Disapproved \\
\hline Tocilizumab & $\mathrm{mAb}$ & anti-inflammatory & Biomanguinhos + Bionovis & Approved \\
\hline
\end{tabular}


TABLE II - Visited websites during the period of December 2017

\begin{tabular}{|c|c|}
\hline Public Companies & Website \\
\hline Bio-Manguinhos & https://www.bio.fiocruz.br/ \\
\hline Fiocruz & https://portal.fiocruz.br/pt-br \\
\hline Butantan & $\begin{array}{l}\text { http://www.butantan.gov.br/Paginas/ } \\
\text { default.aspx }\end{array}$ \\
\hline TECPAR & http://www.tecpar.br/ \\
\hline \multicolumn{2}{|l|}{ Private Companies } \\
\hline Cristália & https://www.2cristalia.com.br/ \\
\hline Eurofarma & http://www.eurofarma.com.br/ \\
\hline Libbs & https://www.libbs.com.br/ \\
\hline Blau & http://www.blau.com.br/ \\
\hline Aché & http://www.ache.com.br/ \\
\hline Biosintética & http://biosintetica.com.br/ \\
\hline Biomm & http://www.biomm.com/pt/ \\
\hline Bionovis & http://bionovis.com.br/ \\
\hline
\end{tabular}

drugs with ANVISA (https://www.cristalia.com.br/ biotecnologia). A phase III clinical trial of Somatotropin is registered at http://ensaiosclinicos.gov.br/rg/RBR$85 \mathrm{bbp} 4 /$, and the equivalent for trastuzumab is registered at http:/clinicaltrials.gov/ct2/show/NCT03242239?ter $\mathrm{m}=$ trastuzumab + crist $\% \mathrm{C} 3 \% \mathrm{~A} 1$ lia\&rank $=1$. Currently, collagenase is the only biopharmaceutical produced by Cristália's biotechnology division, and has been registered with ANVISA and commercialised since 2016. This is the first biopharmaceutical derived from the Brazilian biome. A native strain of Clostridium histolyticum produces the enzyme collagenase by means of anaerobic fermentation, which is marketed as an ointment for the treatment of burns and other skin lesions (Pacheco, 2017). Further efforts are ongoing to develop collagenase for tissue dissociation (e.g. stem cells, isolation of pancreatic islets) as a high-grade ingredient.

Cristália's collagenase is the first biopharmaceutical in the world that not does use animal derivatives for the C. histolyticum culture. This animal-free formulation of collagenase follows the guidelines of the main international regulatory health agencies, avoiding possible contamination with viruses or prion diseases. This aspect allowed Cristália's collagenase to be granted a US patent in 2017, the first time in the history of Brazil that it has been possible to export the technology used to produce a biopharmaceutical (Alegria et al., 2017; Pacheco, 2017).

After extensive searching of the database of medicines registered with ANVISA (ANVISA, 2017) and of the websites of major pharmaceutical and public companies (Table II), the authors of this article could find only two entirely Brazilian biopharmaceuticals that were registered with ANVISA and in commercial production; these were Fiprima $\AA$, a biosimilar produced by Eurofarma, and Kollagenase ${ }^{\circledR}$, produced by Cristália. Other biopharmaceuticals are undergoing the production phase and clinical trials, although due to the confidential nature of the pharmaceutical industry, it is not possible to access these data. For safety reasons, ANVISA requires that all registered biosimilars undergo clinical trials, which is very expensive and time-consuming. There are two ways to register a biosimilar in ANVISA: the first uses a comparison method, and the second involves individual development. The procedures for these are described in RDC n ${ }^{\circ} 55 / 2010$.

In contrast to the very low production of biopharmaceuticals, Brazil is a world reference for the production of vaccines. The SUS makes available approximately 300 million vaccine doses annually, and $96 \%$ of the components are produced nationally, mainly by public companies such as the Butantan Institute and BioManguinhos (http://www.brasil.gov.br/saude/2014/05/ conheca-as-vacinas-oferecidas-pelo-sus).

Butantan Institute produces vaccines against diphtheria, tetanus and pertussis (DTP), adult diphtheria tetanus (dT), infant diphtheria tetanus (DT), recombinant hepatitis B, seasonal trivalent influenza and inactivated rabies. The institute has signed technology transfer agreements (TTA) with Merck Sharp and Dohme Corp to produce a human papillomavirus (HPV) vaccine, and another with GSK for the production of hepatitis A vaccine. In addition, projects are being developed for vaccines against dengue, rotavirus, and recombinant pertussis BCG (neonatal pertussis vaccine) (Butantan Institute website, Table II)

Bio-Manguinhos produces the Haemophilus influenza type A component, which in combination with the diphtheria, tetanus and pertussis components produced by Butantan forms the tetravalent vaccine; through the addition of the hepatitis B component, it also forms the pentavalent vaccine. This company also produces vaccines against yellow fever, Haemophilus influenza type A, meningococcal AB, 10-valent pneumococcus, human rotavirus, a trivalent vaccine (measles, mumps and rubella), and a tetravalent vaccine (chickenpox, measles, mumps and rubella) (Bio-Manguinhos website, Table II).

In Brazil, vaccination is provided free of charge by the government, the Brazilian private vaccine market is therefore still in its infancy (Temporão, 2003), and the domination of public companies in the vaccine market hinders the possibility of private companies venturing 
into vaccine production. The massive public incentives for vaccine production have allowed Brazil to attain a level of excellence in vaccine production, but innovation is guided by the government in this sector. Private companies tend to be more aligned with global innovations and can incorporate new technologies more rapidly than the public authorities. Public and private domains should therefore strike a balance of interests, in order to avoid hampering each other (Rezaie et al., 2012). Recently, following the increase of the number of yellow fever cases in Brazil, Libbs (private) and Bio-Manguinhos (public) have formed a partnership to produce a yellow fever vaccine (http:// portalms.saude.gov.br/noticias/agencia-saude/42403saude-inaugura-nova-linha-de-producao-da-vacina-defebre-amarela).

Biopharmaceuticals have revolutionised the treatment of various diseases, such as cancer, diabetes, genetic disorders and rheumatism. The potential represented by this segment of the market for the pharmaceutical industry is growing, but manufacturing of these substances is expensive and demands both skilled labour and specific plants for production. In Brazil, the costs of biopharmaceuticals are increasing, and represent the largest share of the budget of the SUS. Brazil is dependent on imports of these medicines. The government has invested in PDP via emergency policies. As discussed by Luchese et al. (2017), there are risks to the importing of outdated technology, besides the possibility of the transfer not being effective, resulting in the maintenance of imports to supply the demand. To change these conditions, it is necessary to strengthen the investment in human resources and in $\mathrm{R} \& \mathrm{D}$; this will ensure that the Brazilian technological domain, which has been expanding, has the possibility to introduce technological improvements and to be independent in terms of the creation of new technologies.

The field of traditional, chemically synthesised drugs has been explored for decades by scientists and the pharmaceutical industry. Following advances in genetic engineering, nanotechnology and delivery techniques, biopharmaceuticals now represent a new field to be explored; in practice, treatments with biopharmaceuticals have exceeded the benefits of traditional drug treatments. There are still many barriers to overcome, including the development of new biopharmaceuticals, the scaling-up of production and compatibility with the immune system (in the case of mAbs and therapeutic proteins), and these are big challenges. It is necessary to find a balance between giving people access to better treatment and generating profits for the pharmaceutical industry in return for the high amounts invested in R\&D and the production of these biopharmaceuticals.

\section{FINANCIAL SUPPORT}

This study was financed in part by the Coordenação de Aperfeiçoamento de Pessoal de Nível Superior - Brasil (CAPES) - Finance Code 001 The authors received grants from the State of São Paulo Research Foundation (FAPESP/Brazil, processes number 2013/08617 - 7 and 2015/07749-2).

The authors declare no conflict of interest.

\section{REFERENCES}

Alegria MC, Fardelone LC, Delalana MBR, Thiemann JE, Astolfi Filho S, Moreira RCD, et al. Animal product-free culture medium and a process for producing a supernatant of clostridium comprising one or more collagenolytic and gelatinolytic proteases. Patent No. US 9725692 B2. Cristalia Produtos Quimicos Farmaceuticos Ltda, 2017.

Agência Nacional de Vigilância Sanitária (ANVISA). 2017 http://portal.anvisa.gov.br/consulta-produtos-registrados, accessed $7^{\text {th }}$ December 2017.

Avramis VI. Asparaginases: Biochemical pharmacology and modes of drug resistance. Anticancer Res. 2012;32(7):2423-38.

Brasil. Ministério da Saúde. Secretaria de Ciência, Tecnologia e Insumos Estratégicos, Secretaria de Atenção a Saúde, Departamento de Atenção Especializada e Temática - Nota Informativa Conjunta $n^{\circ} 01 / 2017$. Brasília 21 de fevereiro de 2017a. [cited 07 Dec 2017]. Available from: http:// portalarquivos.saude.gov.br/images/pdf/2017/marco/07/ Nota\%20Informativa\%20Conjunta\%2001-2017\%20DAFDAET.pdf.

Brasil. Ministério da Saúde. Portaria $n^{\circ} 704$. Diário Oficial da União (DOU) 08 mar 2017b; 33; Seção 1. Available from: http:// portalsaude.saude.gov.br/index.php?option $=$ com_content\&vie $\mathrm{w}=$ article $\& \mathrm{id}=10574 \&$ Itemid $=574$.

Brasil. Ministério da Saúde. Secretaria de Ciência, Tecnologia e Insumos Estratégicos, Departamento do Complexo Industrial e Inovação em Saúde, Informe Técnico 02/2017 Assunto: Informações sobre as novas propostas de Parcerias para o Desenvolvimento Produtivo para o ano de 2017. 2017c.

CADE. Conselho Administrativo de Defesa Econômica, 2013 [cited 2017 Dec 07] Available from: http://www.cade.gov. br/noticias/cade-aprova-criacao-de-empresa-nacional-debiofarmacos). 
Diário Oficial da União. DOU. Resolução nº 2.897, 19 October 2015.

Diário Oficial da União. DOU. Portaria nº 731, 26 March 2018.

Durocher Y, Butler M. Expression systems for therapeutic glycoprotein production. Curr Opin Biotechnol. 2009;20(6):700707.

Ferreira B. Produção Pública de Insulina. Cad Farmanguinhos. 2008:4:1-36.

Food and Drug Administration (FDA). 2017. [cited $7^{\text {th }}$ Dec 2017]. Available from: https://www.fda.gov/AboutFDA/ Transparency/Basics/ucm194516.htm, accessed

Goeddel DV, Kleid DG, Bolivar F, Heyneker HL, Yansura DG, Crea R, et al. Expression in Escherichia coli of chemically synthesized genes for human insulin. Proc Natl Acad Sci USA. 1979;76(1):106-110.

Ho PL, Miyaji EN, Oliveira MLS, Dias WO, Kubrusly FS, Tanizaki MM, et al. Economical value of vaccines for the developing countries: The case of Instituto Butantan, a public institution in Brazil. PLoS Negl Trop Dis. 2011;5(11):e1300.

Jozala FA, Geraldes DC, Tundisi LL, Feitosa VA, Breyer CA, Cardoso SL, et al. Biopharmaceuticals from microorganisms: From production to purification. Braz J Microbiol. 2016;47(S):51-63.

Kalden JR, Schulze-Koops H. Immunogenicity and loss of response to TNF inhibitors: Implications for rheumatoid arthritis treatment. Nat Rev Rheumatol. 2017;13(187):707-718.

Kesik-Brodacka M. Progress in biopharmaceutical development. Biotechnol Appl Biochem. 2018;65(3):306-322.

Luchese MD, Bertolini SR, Moro AM, Laurentis AL. Dependência tecnológica na produção de imunobiológicos no Brasil: Transferência de tecnologia $\mathrm{x}$ pesquisa nacional. Univ Soc. 2017;59:46-59.
Pacheco OC. Industrial production of therapeutic enzymes from bacteria of Brazilian biodiversity. Speciality Chemicals Magazine. 2017;37:42-43.

Portal da Saúde. [cited 2017 Dec 07]. Available from: http:// portalsaude.saude.gov.br/index.php/cidadao/principal/agenciasaude/16106-ministerio-da-saude-apresenta-para-a-industrialista-de-produtos-prioritarios.

Rezaie R, McGahan AM, Frew SE, Daar AS, Singer PA. Emergence of biopharmaceutical innovators in China, India, Brazil, and South Africa as global competitors and collaborators. Health Res Policy Syst. 2012;10(18):1-13.

Scott AM, Allison JP, Wolchok JD. Monoclonal antibodies in cancer therapy. Cancer Immun. 2012;12:14.

Temporão JG. The private vaccines market in Brazil: Privatization of public health. Cad. Saúde Pública, Rio de Janeiro. 2003;19(5):1323-39.

Tibaldi JM. Evolution of insulin development: Focus on key parameters. Adv Ther. 2012;29(7):590-619.

Transparency Market Research. [cited 2018 Jun 07. Available from: https://www.transparencymarketresearch.com/ pressrelease/biological-drugs-market.htm.

Tsai H, Hsu P. Cancer immunotherapy by targeting immune checkpoints: Mechanism of $\mathrm{T}$ cell dysfunction in cancer immunity and new therapeutic targets. J Biomed Sci. 2017;24(35):1-8.

Tsuruta LR, Santos ML, Moro AM. Biosimilars advancements: Moving on to the future. Biotechnol Prog. 2015;31(5):1139-49.

United Nations Educational, Scientific and Cultural Organization. UNESCO Science Report: Towards 2030. Paris, France; 2015.

Walsh G. Biological benchmarks. Nat Biotechnol. 2014;32(10):992-1000.

Received for publication on $18^{\text {th }}$ December 2017 Accepted for publication on $23^{\text {rd }}$ August 2018 